\title{
DETERMINANTS OF INDONESIA'S INCOME VELOCITY OF MONEY
}

\author{
Susan Sunila Sharma ${ }^{1}$, Ferry Syarifuddin ${ }^{2}$ \\ ${ }^{1}$ Centre for Financial Econometrics, Deakin Business School, Deakin University, \\ Melbourne, Australia. Email: s.sharma@deakin.edu.au \\ ${ }^{2}$ Bank Indonesia Institute, Bank Indonesia, Jakarta, Indonesia. Email: ferry.s@bi.go.id
}

\begin{abstract}
Using monthly time-series data and both short-and long-run models, our paper examines the determinants of Indonesia's income velocity of money. Our findings suggest that in the long-run, tax revenue, short-term interest rate, industrial production and, in the short-run, money demand, significantly determine income velocity of money. Our analysis suggests that the effect on income velocity is mostly over the long-run as most determinants are dormant in the short-run. The implication from a policy perspective is that shocks are unlikely to burden income velocity over short time horizons.
\end{abstract}

Keywords: Income velocity of money; Unit root; Cointegration; Long-run and short-run elasticities.

JEL Classification: E4; E5.

Article history:

Received : September 15, 2018

Revised : January 5, 2019

Accepted : January 5, 2019

Available online : January 30, 2019

https://doi.org/10.21098/bemp.v21i3.1006 


\section{INTRODUCTION}

There is voluminous literature arguing that the change in velocity of money can be explained by the information contained in several types of macroeconomic and non-macroeconomic variables (see for instance, Pierce and Thomson, 1972; Poole, 1970; McGibany and Nouraz, 1985; Bordo and Jonung, 1981, 1990; Bordo, Jonung, and Siklos, 1993; Ireland, 1991). This literature has two main strands. The first strand of literature owes to the seminal work of Pierce and Thomson (1972) and Poole (1970). These studies establish a standard model of velocity growth where they regress velocity of money on gross national product (GNP), money demand, and short-term interest rate. McGibany and Nouraz (1985) was the first study to test the tax-velocity hypothesis. In other words, they extend the standard model of velocity growth by including income tax as an additional determinant of the velocity of money. They show that income taxes have a statistically significant effect on velocity of income and when excluded from the standard model of velocity growth there is an overprediction of the velocity of money growth. In other words, they provide evidence that the inclusion of taxes in a model of velocity helps alleviate the overprediction of the velocity growth rate.

The second strand of literature typically debates the possible factors that can explain the positive association between income per capita and the moneyto-GDP ratio (or a falling monetary velocity). These possible factors include institutional changes, financial innovations, improvements in communications and information-gathering technologies, and changes in the composition of output (see, for example, Friedman and Schwartz, 1963; Bordo and Jonung, 1981, 1990; Chandavarkar, 1977). The most recent study by Mele and Stefanski (2018) documents that monetary velocity declines with economic growth. They further explain that this negative relationship is due to the process of structural transformation; that is, a shift of workers from agricultural to non-agricultural production associated with rising income.

One limitation of the extant literature on understanding the changes in income velocity is that it mostly focuses on the USA. There is limited attempt made to examine the determinants of income velocity of money in emerging and developing economies (see for instance, Akinlo, 2012; Okafor et al., 2013; Short, 2007; Altayee and Adam, 2013). The main motivation of our study is to fill this research gap.

Our paper, therefore, relates to the first strand of literature on income velocity of money. Our objective is to examine the determinants of income velocity of money in the case of Indonesia. An analysis on the determinants of income velocity of money is essential in the design of credible monetary policy in Indonesia. Understanding money velocity is important because it can offer valuable information for policy makers when it comes to measuring the effectiveness of monetary policy in the country (see for instance: Akinlo, 2012 and Okafor et al., 2013). As one of the fastest growing economies, Indonesia is currently facing several issues in the financial sector, such as financial innovation and a cash-less society (e-money, online payment). These issues are expected to affect the behaviour of income velocity of money in Indonesia (see Okafor et al., 2013).

In the pursuit of understanding the evolution of income velocity of money, we adopt the model proposed by McGibany and Nouraz (1985). More specifically, we regress income velocity of money on Indonesia's industrial production, money 
demand, tax revenue, and short-term interest rate. We use monthly data for income velocity of money, domestic government tax revenue, short-term interest rates, and money demand (M1 and M2) over the period December 2000 to December 2017.

Three steps are implemented to achieve the paper's aim. First, we examine the presence of unit root and search for structural breaks in the data. This is important because in a recent study, Sharma, Tobing, and Azwar (2018) show that almost all 33 Indonesian macroeconomic time-series data have undergone structural breaks. Breaks can influence relationships and can therefore have implications for robustness of results. In the second step, we use the autoregressive distributed lag (ARDL) model to perform the bounds test for cointegration. The proposed ARDL model allows us to examine the null hypothesis of no cointegration between income velocity of money and tax revenue, short-term interest rates, money demand, and industrial production. In the final step, we examine the short-run and long-run elasticities. To extract the long-run relationship, we use three different estimators, namely the ordinary least squares (OLS), the dynamic OLS (DOLS), and the robust least squares (robust LS). Multiple estimators are preferred in order to judge robustness. Additionally, short-run elasticities are derived using an error correction model.

Our work contributes to the literature that examines the determinants of income velocity of money (see, for example, Pierce and Thomson, 1972; Poole, 1970; McGibany and Nouraz, 1985; Bordo and Jonung, 1981, 1990; Bordo et al., 1993; Ireland, 1991). More specifically, our main contribution is directly to the literature testing and confirming that in the long-run, four out of five determinants, namely tax revenue, short-term interest rates, and industrial production, significantly determine income velocity of money. The only exception is money demand for which we find limited statistical evidence. In the short-run, we find strong evidence that past information contained in income velocity of money and money demand significantly determine income velocity of money. We find limited statistical evidence with respect to other three determinants (tax revenue, short-term interest rate, and industrial production). Our results are robust to different estimators (OLS, DOLS, and dynamic LS) used in determining long-run elasticities, as well as to the inclusion of structural break dummy variables in determining the short-run elasticities.

It is worth noting that in prior literature, authors have generally used the OLS estimator to examine the determinants of income velocity of money. Here, we have performed a robustness check based on using multiple estimators. Moreover, we have used the ARDL bounds test for cointegration to examine longrun relationships among variables. The ARDL approach is ideal for our paper's research question given that it allows variables to enter the model at any order of integration. In addition, our approach enables us to examine the determinants of income velocity of money in the short- as well as the long-run. It is not essential that variables that determine the income velocity of money in the short-run do also determine the velocity in the long-run. In this regard, it is important to note that prior literature focuses mostly on the short-run relationship (see for instance, McGibany and Nouraz, 1985). In this regard, that we find long-run determinants 
relatively more important is a significant result in motivating future studies not to ignore possible long-run relations.

Finally, another distinction between our paper and the literature is that we have considered structural breaks in our data and have modelled them. This is important given we are observing data over a period which has experienced several shocks, such as global financial crisis (GFC), as documented in Sharma et al. (2018). However, the effect of GFC on different countries varies and the speed at which the effect is felt is likely to be country-dependent. To model this, and for that matter any other shock, we proceed to first identifying structural breaks in the data and then using these breaks in an augmented velocity model. None of the prior studies considered the role of structural breaks in data. We do, thus providing an extension of the model along the lines that shocks are not ignored. Overall, then, our paper is different both in terms of approach and use of methods and is focussed on establishing the robustness of our main conclusions.

The balance of the paper is organized as follows. Section II discusses data and methodology. We discuss our main findings in Section III and, in the final section, we provide concluding remarks.

\section{DATA AND METHODOLOGY}

A. Data

The data used in this study is partially adopted from Narayan, Narayan, Rahman, and Setiawan (2018). In particular, our data include monthly industrial production, real money demand (M1 and M2), velocity of M1 and M2 (which we refer to as V1 and V2, respectively), and 1-month and 3-month real interest rates between Indonesia and the USA. In addition, we have also used annual data on revenue from Indonesia's government tax and converted it into monthly frequency using linear interpolation method. ${ }^{3}$ Our data spans the period December 2000 to December 2017. The final chosen sample is dictated by data availability. All data (except V1 and V2) are sourced from the Bloomberg database. Data on V1 and V2 are sourced from Bank Indonesia.

\section{B. Methodology}

B.I. Long-Run Model

The prior literature on the determinants of income velocity of money remains controversial. Therefore, before we propose our empirical model, we first provide a brief discussion of the theories that motivate the inclusion of variables we model. Understanding fluctuations of velocity is important because it enables us to gauge the role of money in business cycle formation. Jung (2017), for instance, documents that changes in the money stock are important sources of output fluctuations. He further explains that this view leads to the assumption that velocity is a stable

\footnotetext{
3 There is no available monthly data on tax revenue for Indonesia, thus, we use linear interpolation method to convert tax revenue data from annual to monthly frequency. Linear interpolation is simply a method of curve fitting using a linear polynomial to construct new data points within the range of a discrete set of known data points.
} 
function of macro variables, such as interest rates. In fact, income velocity of money is simply a ratio of real output to the stock of money. Thus, anything that affects real output and the stock of money (money demand) will have a direct effect on the income velocity of money. Therefore, McGibany and Nouraz (1985) explain that velocity of money is affected by cyclical and secular factors, in which GDP fluctuates over a business cycle. In other words, we may expect velocity to rise in expansions and fall in recessions (see Thornton, 1983).

Furthermore, McGibany and Nouraz (1985) also explain the inverse relationship between income velocity of money and stock of money (or money demand). In other words, it is expected that velocity will increase with the opportunity cost of holding money. Thus, we conclude that there is a direct relationship between the rate of interest and inflation and the velocity of money because the decision to hold money is simply affected by the expectations of future inflation and changes in interest rates. Tatom (1983) argues that changes in money demand may lead to a change in a country's output with several periods of lags. This simply implies that changes in money demand in any period may produce less than a proportionate change in output in that period, which may lead to a decrease in velocity. Given these arguments, the prior literature includes some proxies for cyclical and secular factors (such as market interest rates, inflation rate, and changes in money stock) in modelling determinants of income velocity of money (see, for example, Tatom, 1983 and Thornton, 1983).

However, McGibany and Nouraz (1985) argue that most empirical models which include some or all the above-mentioned factors consistently overpredict velocity of money due to some omitted variables. Thus, they propose that one such variable which may improve the model's power is the income tax rate. They argue that income tax rate and velocity of money do share a significant relationship at least in the short-run if not in the long-run. They explain this relationship as follows:

"For any given level of national income, disposable personal income increases as taxes are reduced. This results in an increase in consumption demand which, in turn, leads to an increase in demand for transactions balances. Nor is businesses' demand for money independent of taxes. For example, consider a reduction in corporate taxes. Then, as Holmes and Smyth (1972) have pointed out, the equilibrium rate of return before taxes must fall, a fact which is normally associated with an increase in capital investment. As a result, businesses' demand for money, which is dependent on capital outlays, will increase. Therefore, the public's demand for transactions balances is inversely related to income taxes. Thus, in the short run, for a given level of national income and rate of interest, a reduction in taxes results in a decrease in the velocity of money" (McGibany and Nouraz, 1985, p. 526).

Therefore, in order to examine the determinants of income velocity of money for Indonesia, we follow McGibany and Nouraz (1985) and employ the following regression model:

$$
\ln V_{t}=\alpha+\delta_{1} \operatorname{lnRev}_{t}+\delta_{2} \ln I R_{t}+\delta_{3} \ln M_{t}+\delta_{4} \ln I P_{t}+\mu_{t}
$$

Here, we use two proxies for income velocity of money ( $V 1$ and $V 2$, denoted $V$ ). The income velocity of money is constructed using the traditional framework 
of the quantity theory of money under which the circulation of money $(M V)$ depends on its demand covering all transactions in an economy $(P Y)$ and is represented by $M V=P Y$. In this relation, $M$ is the nominal money supply defined as $M_{1}$ (or $\left.M_{2}\right) ; V$ is velocity; $P$ is prices and $Y$ is real output. This means that $V=P Y / M$. Additionally, Rev denotes revenue from Indonesia's government tax; $I R$ denotes short-term interest rates (M1IR and M3IR denote, respectively, 1- and 3-month rates); and IP represents industrial production. All variables considered in the above model are in natural logarithm $(l n)$ form. It is worth noting that given we have two proxies for money demand, income velocity of money, and short-term interest rates, we use each proxy at a time in the above model while testing for any long-run relationships (cointegration). These combinations provide altogether eight models, four models for $V 1$ and four models for $V 2$.

\section{B.II. Cointegration}

To test for a long-run relation amongst the variables, we employ an ARDL bounds testing approach for cointegration, which has the following specification:

$$
\begin{aligned}
\Delta \ln V_{t}= & \alpha+\beta_{1} \ln V_{t-1}+\beta_{2} \operatorname{lnRev}_{t-1}+\beta_{3} \ln I R_{t-1}+\beta_{4} \ln M_{t-1}+\beta_{5} \ln I P_{t-1} \\
& +\sum_{i=0}^{3} \gamma_{i} \Delta \ln V_{t-i}+\sum_{j=0}^{3} \gamma_{j} \Delta \ln \operatorname{Rev}_{t-j}+\sum_{k=0}^{3} \gamma_{k} \Delta \ln I R_{t-k} \\
& +\sum_{l=0}^{3} \gamma_{l} \Delta \ln M_{t-l}+\sum_{m=0}^{3} \gamma_{m} \Delta \ln I P_{t-m}+\varepsilon_{t}
\end{aligned}
$$

All the variables used in Equation (2) are defined as in Equation (1). A longrun relationship can be tested using the F-test statistic obtained from the bounds test. More specifically, the F-test statistic examines the joint significance of the one period lagged level variables in Equation (2), that is, $H_{0}: \beta_{1}=\beta_{2}=\beta_{3}=\beta_{4}=\beta_{5}=0$. We examine these hypotheses using the standard Wald (or F-test) statistic. The detailed procedure of examining the null hypothesis of "no cointegration" and the relevant critical values are given in Narayan (2005).

\section{EMPIRICAL RESULTS}

This section is organised into three parts. In the first part, we discuss some key statistical features of the data. The second part of the results explains the findings from the ARDL bounds test for cointegration. In the final part of this section, we discuss results from long-run and short-run models.

\section{A. Preliminary Results}

We begin by discussing the common descriptive statistics of all variables, namely $\ln V 1, \ln V 2, \ln I P, \operatorname{Ln} M 1, \ln M 2, \ln M 1 I R, \ln M 3 I R$, and $\ln R e v$ (see Table 1). Skewness and kurtosis statistics suggest a non-normal distribution for all variables. Additionally, 
we conduct the Jarque-Bera (JB) test, examining the normality of the distribution. In the table, we report the JB test statistics and its $p$-value; see the last two columns. Note that except in the case of $\ln V 1$, the $p$-value for all variables is less than 0.0300 , implying that the normal distribution hypothesis can be safely rejected at least at the $5 \%$ significance level. This means that all variables (except $\ln V 1$ ) are nonnormally distributed.

Table 1.

Descriptive Statistics

This table reports selective descriptive statistics for two proxies of income velocity of money $(\ln V 1$ and $\ln V 2)$, two proxies for money demand ( $\ln M 1$ and $\ln M 2)$, two proxies for short-term interest rates $(\ln M 1 I R$ and $\ln M 3 I R)$, industrial production $(\ln I P)$, and revenue from government tax $(\ln R e v)$. All data are for Indonesia. All variables are considered in natural logarithm form. The basic statistics include the mean value, maximum and minimum values, standard deviation (SD), skewness, kurtosis, and the JarqueBera (JB) test statistic and its corresponding $p$-value.

\begin{tabular}{lcccccccc}
\hline Variables & Mean & Maximum & Minimum & SD & Skewness & Kurtosis & JB-test & $p$-value \\
\hline $\ln V_{1}$ & -0.0693 & 0.1202 & -0.2939 & 0.0857 & 0.0688 & 2.5743 & 1.7099 & 0.4253 \\
$\ln V_{2}$ & -1.5133 & -1.2356 & -1.7992 & 0.1253 & -0.3702 & 2.5430 & 6.4674 & 0.0394 \\
$\ln I P$ & 33.2766 & 33.9068 & 32.7187 & 0.3129 & 0.7420 & 2.2881 & 23.1381 & 0.0000 \\
$\ln M_{1}$ & 13.0420 & 14.1454 & 11.8869 & 0.6696 & -0.1063 & 1.6991 & 14.8416 & 0.0006 \\
$\ln M_{2}$ & 14.4860 & 15.5055 & 13.5127 & 0.6317 & 0.0431 & 1.5983 & 16.8464 & 0.0002 \\
$\ln M_{1} I R$ & 2.0899 & 2.8821 & 1.3825 & 0.3685 & 0.4670 & 2.5970 & 8.8398 & 0.0120 \\
$\ln M_{3} I R$ & 2.0896 & 2.8834 & 1.3825 & 0.3686 & 0.4677 & 2.5948 & 8.8755 & 0.0118 \\
$\ln R E V$ & 12.5039 & 13.4094 & 10.9521 & 0.6900 & -0.4186 & 1.8962 & 16.3923 & 0.0003 \\
\hline
\end{tabular}

Next, we also examine the presence of unit roots in all variables. Even though the bounds test for cointegration does not require pre-examining the order of integration, we need all variables to be I(1) in order to examine the long-run relationship between income velocity of money and its determinants (namely, industrial production, money demand, short-term interest rate, and tax revenue). We use the Augmented Dickey-Fuller (ADF, 1979) unit root test to examine the order of integration and report results in Panel A of Table 2. The ADF test results suggest that the null hypothesis of a unit root is not rejected at the 5\% (or better) significance level for all variables. This implies that all variables are non-stationary in their level form. We have also test for the presence of a unit root in the first difference of all variables. The results presented in the last two columns of the table suggest that we can reject the null hypothesis of a unit root for all variables. This means that all variables are stationary at the first difference stage. 
Table 2.

\section{Unit Root Test Results}

In Panel A of this table, we report Augmented Dickey-Fuller (ADF) unit root test results for all variables considered at level and first difference forms. Column 2 reports ADF $t$-statistics, which examine the null hypothesis of "unit root,". The optimal lag length is in parenthesis. It is chosen using the Schwartz Information Criterion by starting with a maximum of 14 lags. In the last column we report ADF unit root test results for all variables considered as first difference. In Panel B, we report the NP (2010) structural break unit root test results. The NP (2010) unit root test allows for two breaks in level as well as slope. In columns 2 and 3, we report the first and second break dates, respectively. Column 4 reports the break fraction $\left[\lambda_{1}, \lambda_{2}\right]$, and in parenthesis, we report their corresponding $t$-statistics, which determine the statistical significance of the breaks. In column 5 , we report the slope coefficient related to the unit root beta and in parenthesis we report its corresponding $t$-statistic. Results reported in column 5 examine the unit root null hypothesis. The critical values are given in Tables 1 and 2 of NP (2010). The last column reports the optimal lag length used to control for serial correlation. Finally, ${ }^{* * *}$ denotes statistical significance at $1 \%$ level.

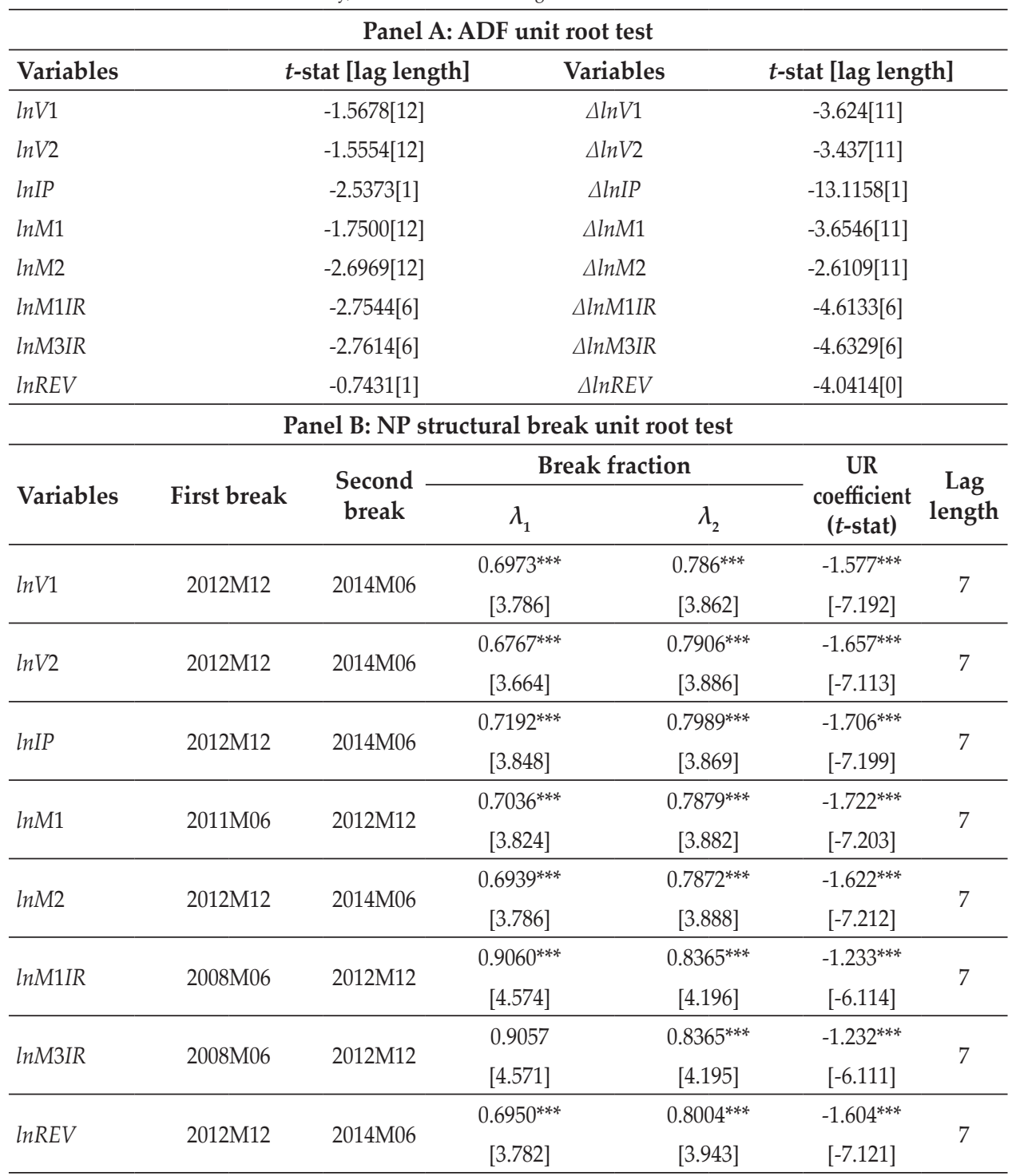


Furthermore, one of the main concerns in this paper is with the implications of the presence of structural breaks in Indonesia's macroeconomic data. This has roots in the work of Sharma et al. (2018), who examine the unit root properties of Indonesia's 33 macroeconomic data series at both the annual and monthly frequencies. They provide mixed evidence of the presence of unit roots and document that almost all macroeconomic data suffer from structural breaks. Thus, we follow their work and examine the presence of two endogenous breaks using the widely used Narayan and Popp (NP, 2010) ${ }^{4}$ structural break unit root test and report results in Panel B of Table 2. Overall, our results imply that that two significant structural breaks characterize our data series. The two common significant break dates obtained are December 2012 and June 2014.

The first structural break (December 2012) is associated with the combined effects of the turbulence in the Indonesian financial market and weakening trade performance. As China's economy deteriorated due to the contraction in global commodity prices, the value of Indonesia's exports declined, particularly from mid-2012. Indonesia also experienced an economic slowdown in 2014. Indonesia's output dropped to 5.1\% in 2014 from 6.5\% in 2011, which is recorded as the slowest growth since 2009. This downtrend of the Indonesian economy was due to both adverse economic performance, as well as negative political influence. The role of public expenditure was modest. Over this period, Bank Indonesia (BI) raised its $\mathrm{BI}$ policy rate several times to combat the accelerating inflation (caused by fuel price hikes), and to curb capital outflows. Indonesian economic slowdown in 2014 was also partly due to the rising uncertainty which was a result of Indonesia's presidential elections. This political uncertainty hurt investments.

\section{B. Cointegration}

The results of the bounds cointegration test are summarised in Table 3. We follow Equation (2), where each variable in the Equation (1) is taken as a dependent variable in the calculation of the $F$-statistic. This exercise results into 32 cointegrating ARDL models and these are accordingly numbered in column 1. In the second column, we report the model specification where the first variable refers to the dependent variable followed by other variables which are considered as independent variables in Equation (2). In other words, models 1-4, 5-8, 9-12, 13-16, 17-24, and 25-32 represent ARDL specifications when we consider $\ln V 1, \ln V 2, \ln M 1, \ln M 2$, $\ln R e v$, and $\ln I P$ as dependent variables, respectively, in Equation (2). In the third column, we note the lag orders of the ARDL specification with respect to the orders of variables listed in column 2. In the final column, we report F-statistics. These F-statistics are then compared against the critical values generated by Narayan (2005) in order to examine the null hypothesis of no cointegration.

4 More details on this method can be found in Monte Carlo results presented in NP (2013). 
Table 3.

ARDL Bound Test Results for Cointegration

This table reports the ARDL bound test results for cointegration. The ARDL model is:

$\Delta \ln V_{t}=\alpha+\beta_{1} \ln V_{t-1}+\beta_{2} \ln \operatorname{Rev}_{t-1}+\beta_{3} \ln I R_{t-1}+\beta_{4} \ln M_{t-1}+\beta_{5} \ln I P_{t-1}+\sum_{i=0}^{3} \gamma_{t} \Delta \ln V_{t-1}+\sum_{j=0}^{3} \gamma_{j} \Delta \ln \operatorname{Rev}_{t-j}+\sum_{k=0}^{3} \gamma_{k} \Delta \ln I R_{t-k}+\sum_{l=0}^{3} \gamma_{l} \Delta \ln M_{t-1}+\sum_{m=0}^{3} \gamma_{m} \Delta \ln I P_{t-m}+\varepsilon_{t^{*}}$

The bounds cointegration test is examined by considering all variables as a dependent variable one at a time within the above ARDL specification. This results in 32 models as noted in column 1 and the ARDL model specification is provided in column 2. We use the Akaike Information Criterion to choose the optimal lags of variables which enter the ARDL specification. We start with a maximum of three lags for the dependent as well as all independent variables. We use the F-test statistic obtained from the bounds test. More specifically, the F-test statistic examines the joint significance of the coefficients on the one period lagged levels of the variables in the above ARDL model, that is, $\mathrm{H}_{0}: \beta_{1}=\beta_{2}=\beta_{3}=\beta_{4}=\beta_{5}=0$. Critical values are obtained from Narayan (2005, pp 1988). Finally, $*(* *)$ denote statistical significance at $10 \%(5 \%)$ levels.

\begin{tabular}{|c|c|c|c|}
\hline Model & Model Specification & ARDL Order & F-statistic \\
\hline 1 & $F_{\operatorname{lnV} 1}(\ln V 1 \mid \ln R E V, \ln M 1 I R, \ln M 1, \ln I P)$ & $\operatorname{ARDL}(3,1,3,3,1)$ & 2.3401 \\
\hline 2 & $F_{\ln V 1}(\ln V 1 \mid \ln R E V, \ln M 3 I R, \ln M 1, \ln I P)$ & $\operatorname{ARDL}(3,1,3,3,1)$ & 2.3271 \\
\hline 3 & $F_{\ln V 1}(\ln V 1 \mid \ln R E V, \ln M 1 I R, \ln M 2, \ln I P)$ & $\operatorname{ARDL}(2,1,1,2,2)$ & $3.5176^{*}$ \\
\hline 4 & $F_{\ln V 1}(\ln V 1 \mid \ln R E V, \ln M 3 I R, \ln M 2, \ln I P)$ & $\operatorname{ARDL}(2,1,1,2,2)$ & $3.5045^{*}$ \\
\hline 5 & $F_{\ln V 2}(\ln V 2 \mid \ln R E V, \ln M 1 I R, \ln M 1, \ln I P)$ & $\operatorname{ARDL}(3,1,1,3,3)$ & 1.2255 \\
\hline 6 & $F_{\ln V 2}(\ln V 2 \mid \ln R E V, \ln M 13 R, \ln M 1, \ln I P)$ & $\operatorname{ARDL}(3,1,1,3,3)$ & 1.2307 \\
\hline 7 & $F_{\ln V 2}(\ln V 2 \mid \ln R E V, \ln M 1 I R, \ln M 2, \ln I P)$ & $\operatorname{ARDL}(3,1,1,3,1)$ & 1.9208 \\
\hline 8 & $F_{\ln V 2}(\ln V 2 \mid \ln R E V, \ln M 3 I R, \ln M 2, \ln I P)$ & $\operatorname{ARDL}(3,1,1,3,1)$ & 1.9215 \\
\hline 9 & $F_{\ln M 1}(\ln M 1 \mid \ln R E V, \ln M 1 I R, \ln V 1, \ln I P)$ & $\operatorname{ARDL}(3,1,3,3,1)$ & 1.963 \\
\hline 10 & $F_{\ln M 1}(\ln M 1 \mid \ln R E V, \ln M 3 I R, \ln V 1, \ln I P)$ & $\operatorname{ARDL}(3,1,3,3,1)$ & 1.9519 \\
\hline 11 & $F_{\ln M 1}(\ln M 1 \mid \ln R E V, \ln M 1 I R, \ln V 2, \ln I P)$ & $\operatorname{ARDL}(3,1,1,3,1)$ & 2.1097 \\
\hline 12 & $F_{\ln M 1}(\ln M 1 \mid \ln R E V, \ln M 3 I R, \ln V 2, \ln I P)$ & $\operatorname{ARDL}(3,1,1,3,1)$ & 2.1093 \\
\hline 13 & $F_{\ln M 2}(\ln M 2 \mid \ln R E V, \ln M 1 I R, \ln V 1, \ln I P)$ & $\operatorname{ARDL}(2,1,1,2,1)$ & $4.6845^{* *}$ \\
\hline 14 & $F_{\ln M 2}(\ln M 2 \mid \ln R E V, \ln M 3 I R, \ln V 1, \ln I P)$ & $\operatorname{ARDL}(2,1,1,2,1)$ & $4.6896^{* *}$ \\
\hline 15 & $F_{\ln M 2}(\ln M 2 \mid \ln R E V, \ln M 1 I R, \ln V 2, \ln I P)$ & $\operatorname{ARDL}(3,1,1,3,1)$ & 3.3443 \\
\hline 16 & $F_{\ln M 2}(\ln M 2 \mid \ln R E V, \ln M 3 I R, \ln V 2, \ln I P)$ & $\operatorname{ARDL}(3,1,1,3,1)$ & 3.3427 \\
\hline 17 & $F_{\text {lnREV }}(\ln R E V \mid \ln M 1, \ln M 1 I R, \ln V 1, \ln I P)$ & $\operatorname{ARDL}(1,1,1,1,1)$ & 2.2375 \\
\hline 18 & $F_{\ln R E V}(\ln R E V \mid \ln M 1, \ln M 3 I R, \ln V 1, \ln I P)$ & $\operatorname{ARDL}(1,1,1,1,1)$ & 2.2395 \\
\hline 19 & $F_{\ln R E V}(\ln R E V \mid \ln M 1, \ln M 1 I R, \ln V 2, \ln I P)$ & $\operatorname{ARDL}(1,1,1,1,1)$ & 3.4478 \\
\hline 20 & $F_{\text {lnREV }}(\ln R E V \mid \ln M 1, \ln M 3 I R, \ln V 2, \ln I P)$ & $\operatorname{ARDL}(1,1,1,1,1)$ & 3.4486 \\
\hline 21 & $F_{\text {lnREV }}(\ln R E V \mid \ln M 2, \ln M 1 I R, \ln V 1, \ln I P)$ & $\operatorname{ARDL}(1,1,1,1,1)$ & 1.7956 \\
\hline 22 & $F_{\ln R E V}(\ln R E V \mid \ln M 2, \ln M 3 I R, \ln V 1, \ln I P)$ & $\operatorname{ARDL}(1,1,1,1,1)$ & 1.7957 \\
\hline 23 & $F_{\text {lnREV }}(\ln R E V \mid \ln M 2, \ln M 1 I R, \ln V 2, \ln I P)$ & $\operatorname{ARDL}(1,1,1,1,1)$ & 2.1306 \\
\hline 24 & $F_{\operatorname{lnREV}}(\ln R E V \mid \ln M 2, \ln M 3 I R, \ln V 2, \ln I P)$ & $\operatorname{ARDL}(1,1,1,1,1)$ & 2.1277 \\
\hline 25 & $F_{\ln I P}(\ln I P \mid \ln M 1, \ln M 1 I R, \ln V 1, \ln R E V)$ & $\operatorname{ARDL}(2,3,1,2,1)$ & 1.8806 \\
\hline 26 & $F_{\ln I P}(\ln I P \mid \ln M 1, \ln M 3 I R, \ln V 1, \ln R E V)$ & $\operatorname{ARDL}(2,3,1,2,1)$ & 1.8842 \\
\hline 27 & $F_{\ln I P}(\ln I P \mid \ln M 1, \ln M 1 I R, \ln V 2, \ln R E V)$ & $\operatorname{ARDL}(2,3,1,2,1)$ & 2.1377 \\
\hline 28 & $F_{\operatorname{lnIP}}(\ln I P \mid \ln M 1, \ln M 3 I R, \ln V 2, \ln R E V)$ & $\operatorname{ARDL}(2,3,1,2,1)$ & 2.1419 \\
\hline 29 & $F_{\ln I P}(\ln I P \mid \ln M 2, \ln M 1 I R, \ln V 1, \ln R E V)$ & $\operatorname{ARDL}(2,1,1,3,1)$ & 1.8746 \\
\hline 30 & $F_{\ln I P}(\ln I P \mid \ln M 2, \ln M 3 I R, \ln V 1, \ln R E V)$ & $\operatorname{ARDL}(2,1,1,3,1)$ & 1.877 \\
\hline 31 & $F_{\ln I P}(\ln I P \mid \ln M 2, \ln M 1 I R, \ln V 2, \ln R E V)$ & $\operatorname{ARDL}(2,3,1,2,1)$ & 2.1563 \\
\hline 32 & $F_{\ln I P}(\ln I P \mid \ln M 2, \ln M 3 I R, \ln V 2, \ln R E V)$ & $\operatorname{ARDL}(2,3,1,2,1)$ & 2.1583 \\
\hline
\end{tabular}


We find significant evidence of cointegration only in four out of 32 model specifications. These are models 3-4 and 13-14, where we consider $\ln V 1$ and $\ln M 2$ as dependent variable. More specifically, when we consider $\ln V 1$ as a dependent variable, the evidence of cointegration is found only when we use $\ln M 2$ as a proxy for money demand. There is no significant evidence of cointegration when we consider $\ln M 1$ as a proxy for money demand. Additionally, the evidence of cointegration is similarly reported for $\ln M 2$ as a dependent variable when $\ln V 1$ is considered as a proxy for income velocity of money and no cointegration is found when $\ln V 2$ is considered. For the other (28/32) remaining models, we do not find any evidence of cointegration.

Thus, overall, our results imply that there exists a long-run relationship only when we consider $\ln V 1$ as a proxy for income velocity of money and $\ln M 2$ as a proxy for money demand. There is no such evidence when we consider $\ln V 2$ as a proxy.

\section{Long-run and Short-run Elasticities}

This section's main objective is to examine the short- and long-run determinants of income velocity of money. Thus, we will only consider models where our dependent variable is either $\ln V 1$ or $\ln V 2$. We will examine the long-run elasticities by estimating Equation (1) only for two models (models 3-4), where we found evidence of cointegration. The long-run results are provided in Panel A of Table 4. More specifically, we report results for these two models where we consider: (1) $\ln V 1$ as a dependent variable and $\ln R e v, \ln M 1 I R, \ln M 2$, and $\ln I P$ as independent variables; and (2) $\ln V 1$ as a dependent variable and $\ln R e v, \ln M 3 I R, \ln M 2$, and $\ln I P$ as independent variables. We report variable coefficient and its corresponding $p$-values in parenthesis. We use Newey-West (1987) standard errors to control for any autocorrelation and heteroskedasticity in error-terms of Equation (1). Our results suggest that Indonesia's tax revenue, short-term interest rates, and industrial production are statistically significant determinants of $\ln V 1$. We also note that the sign on tax revenue and short-term interest rates are positive, whereas industrial production has a negative influence on the income velocity of money. We note that money demand $(\ln M 2)$ is a statistically insignificant determinant of $\ln V 1$. Our results are consistent with the findings of McGibany and Nourzad (1985).

Table 4.

\section{Long-run Elasticities}

In this table, we report results for the long-run relationship between money demand and other independent variables for which we find evidence of cointegration, as documented in Table 3. In particular, we have used three estimators, namely, the OLS, DOLS, and robust LS, and report results in Panels A, B, and C, respectively. In all the cases, we have used the Newey-West standard errors to control for autocorrelation in the residuals. In order to obtain the DOLS estimator, we include a maximum of three leads and three lags of the first difference cointegrating variables in the following long-run model specification: $\ln V_{t}=\alpha+\delta_{1} \operatorname{lnRev}_{t}+\delta_{2} \ln I R_{t}+\delta_{3} \ln M_{t}+\delta_{4} \ln I P_{t}+\mu_{t}$. Finally, ${ }^{* * *}, * *$, and ${ }^{*}$ denote statistical significance at the $1 \%, 5 \%$, and $10 \%$ levels, respectively.

\begin{tabular}{lcccccc}
\hline \multicolumn{7}{c}{ Panel A: OLS Estimators } \\
\hline \multirow{2}{*}{ Model } & $\begin{array}{c}\text { Dependent } \\
\text { Variable }\end{array}$ & $\ln R e v$ & $\ln M 1 I R$ & $\ln M 3 I R$ & $\ln M 2$ & $\ln I P$ \\
\hline 3 & $\ln V 1$ & $0.2989^{* * *}$ & $0.0884^{* * *}$ & - & -0.1434 & $-0.1901^{* * *}$ \\
& & {$[0.0002]$} & {$[0.0001]$} & & {$[0.1251]$} & {$[0.0002]$} \\
4 & $\ln V 1$ & $0.2989^{* * *}$ & - & $0.0879^{* * *}$ & -0.1438 & $-0.1897^{* * *}$ \\
& & {$[0.0002]$} & & {$[0.0001]$} & {$[0.1245]$} & {$[0.0003]$} \\
\hline
\end{tabular}


Table 4.

Long-run Elasticities (Continued)

\begin{tabular}{|c|c|c|c|c|c|c|}
\hline \multicolumn{7}{|c|}{ Panel B: DOLS Estimators } \\
\hline Model & $\begin{array}{c}\text { Dependent } \\
\text { Variable }\end{array}$ & $\ln \operatorname{Rev}$ & $\ln M 1 I R$ & $\ln M 3 I R$ & $\ln M 2$ & $\ln I P$ \\
\hline 3 & $\ln V 1$ & $\begin{array}{c}0.3099^{* * *} \\
{[0.0011]}\end{array}$ & $\begin{array}{c}0.0947^{* * *} \\
{[0.0013]}\end{array}$ & - & $\begin{array}{c}-0.1242 \\
{[0.2961]}\end{array}$ & $\begin{array}{c}-0.2297^{* * *} \\
{[0.0008]}\end{array}$ \\
\hline 4 & $\ln V 1$ & $\begin{array}{c}0.3099^{* * *} \\
{[0.0011]}\end{array}$ & - & $\begin{array}{c}0.0947^{* * *} \\
{[0.0031]}\end{array}$ & $\begin{array}{c}-0.1244 \\
{[0.2954]}\end{array}$ & $\begin{array}{c}-0.2296^{* * *} \\
{[0.0008]}\end{array}$ \\
\hline \multicolumn{7}{|c|}{ Panel C: Robust LS Estimators } \\
\hline 3 & $\ln V 1$ & $\begin{array}{c}0.3171^{* * *} \\
{[0.0000]}\end{array}$ & $\begin{array}{l}0.0937^{* *} \\
{[0.0000]}\end{array}$ & - & $\begin{array}{c}-0.1484^{* * *} \\
{[0.0028]}\end{array}$ & $\begin{array}{c}-0.2196^{* * *} \\
{[0.0000]}\end{array}$ \\
\hline 4 & $\ln V 1$ & $\begin{array}{c}0.3168^{* * * *} \\
{[0.0000]}\end{array}$ & - & $\begin{array}{c}0.0935^{* * *} \\
{[0.0000]}\end{array}$ & $\begin{array}{c}-0.1483^{* *} \\
{[0.0028]}\end{array}$ & $\begin{array}{c}-0.2195^{* * * *} \\
{[0.0000]}\end{array}$ \\
\hline
\end{tabular}

Additionally, for robustness check, we consider two other long-run estimators, namely the DOLS and robust LS, and report results in Panels B and C, respectively, of Table 3. In the case of the DOLS estimator, we use a maximum of three leads and three lags of first differenced cointegrating variables in Equation (1). Again, we correct for standard errors using the Newey-West procedure. Our results are robust to all three different estimators. The only exception is $\ln M 2$ which becomes a significant determinant of $\ln V 1$ when we use the robust LS estimator compared to the other two estimators.

Next, we examine short-run elasticities between income velocity of money and its determinants (namely, money demand, industrial production, tax revenue, and short-term interest rates). In total, we estimate eight models: four models relate to when we consider the first difference of $\ln V 1$ as a dependent variable and the other four models are those in which we have the first difference of $\ln V 2$ as a dependent variable. The short-run results are reported in Table 5. The lag orders of the ARDL model are obtained through two steps: (1) we estimate an ARDL model with a maximum of three lags of the dependent variable and three lags of all independent variables; and (2) from step (1), we identify those lags for which we find statistically significant coefficients and consider these as final lag orders for our final estimated model. These lag orders are provided in row 2 of Table 5. To understand this, consider, for instance, results reported in column 2: here, we follow the ARDL lag order of $(3,0,0,3,1)$ for variables $\Delta \ln V 1, \Delta \operatorname{lnRev,} \Delta \operatorname{lnM} M I R$, $\triangle \ln M 1$, and $\triangle \ln I P$, respectively.

Now, we discuss results from Panel A for the four ARDL models where we consider $\Delta \ln V 1$ as a dependent variable. Results reported in columns 2 and 3 indicate that all three lags of the dependent variable, $\Delta \ln V 1$, contemporaneously, as well as all three lags of $\Delta l n M 1$ have statistically significant effects on $\Delta l n V 1$. Additionally, we find that in the short-run, industrial production (except first lag of $\triangle \ln I P$ ) and short-term interest rates do not have any statistically significant effect on the income velocity of money. It is important to note that for two out of four models where we consider $\ln M 2$, instead of $\ln M 1$ as a proxy for money demand, as a determinant of $\ln V 1$, we had earlier reported evidence of cointegration. Therefore, we estimate the error correction model (ECM) within an ARDL framework for these two models and report results in columns 4 and 5. Our results indicate that $E C M_{t-1}$ is negative and statistically significant in one out of the two models. 


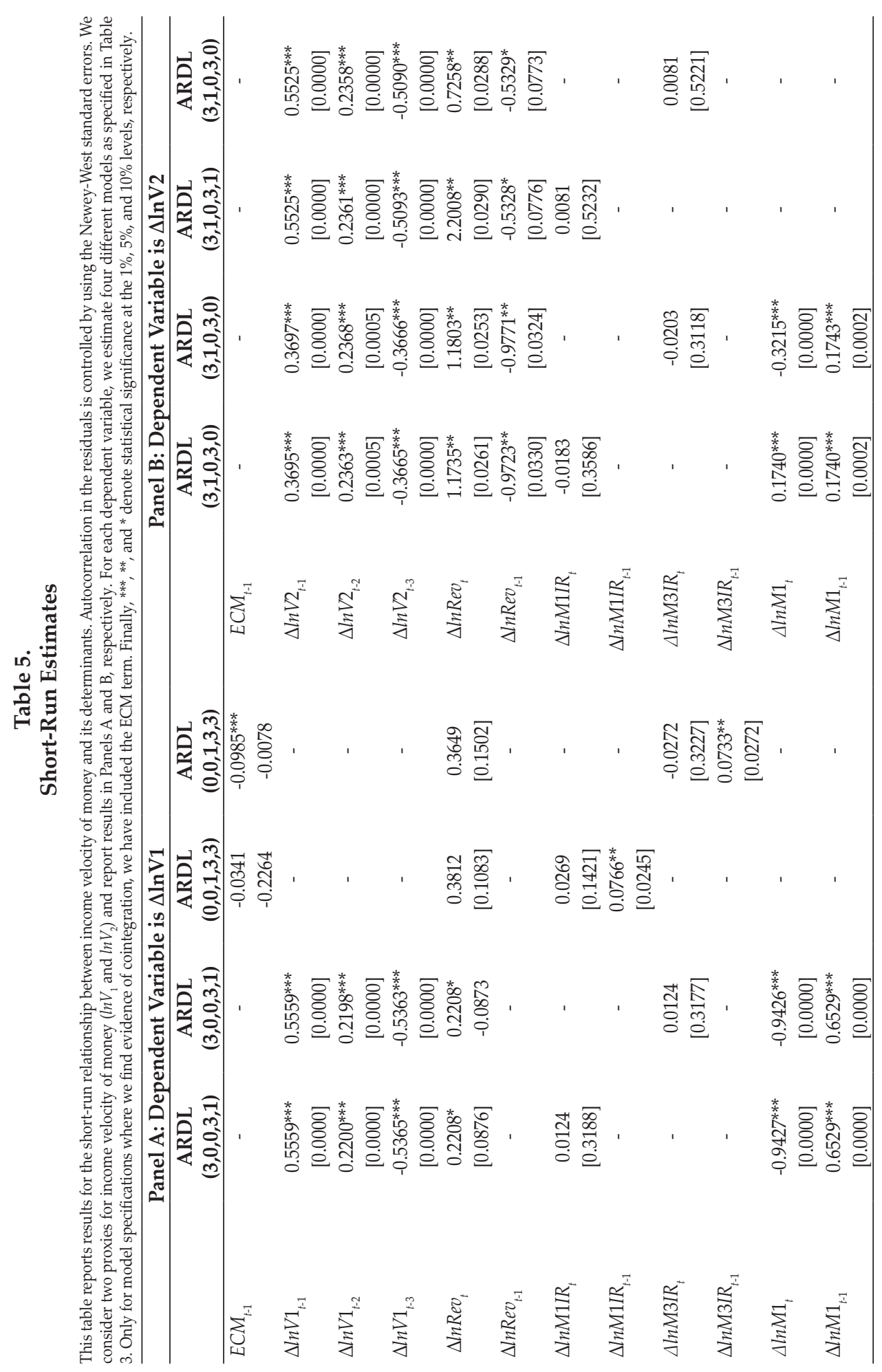




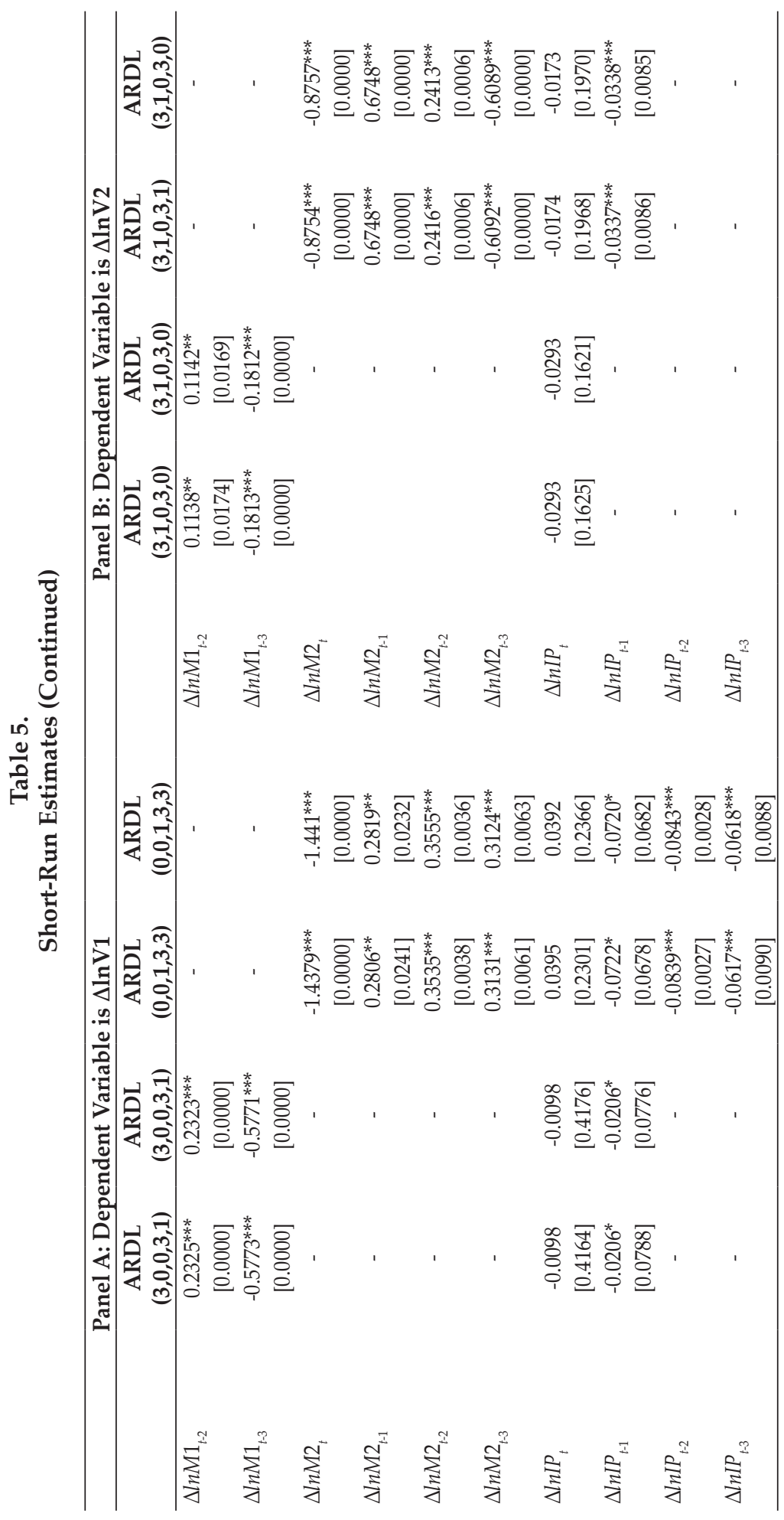


The magnitude of the ECM term suggests that a deviation from the equilibrium level of $\ln V 1$ during the current period will be corrected by $10 \%$ in the next period. Moreover, we also find that the contemporaneous effect and all three-lag effects of $\Delta l n M 2$ have a statistically significant effect on income velocity of money. We also note that in these two models, all three lags of $\Delta l n I P$ have a statistically significant effect on $\Delta \ln V 1$.

Our next set of results occupy Panel B, where we consider $\Delta \ln V 2$ as a dependent variable. Once again, we estimate four ARDL models, however, for none of these models we consider and ECM term because we did not find cointegration for these model specifications. Our results are somewhat consistent with what we discussed earlier. First, we note that irrespective of the model specification, all three lags of the dependent variable as well as the contemporaneous and all three lags of money demand ( $\triangle \ln M 1$ and $\Delta \operatorname{lnM} 2)$ are statistically significant in the short-run. In addition, we also note that the contemporaneous and one period lag of $\Delta \ln R e v$ have a positive and statistically significant effect on $\Delta \ln V 2$.

The overall observation from our analysis is that there is strong evidence in support of money demand and tax revenue as significant determinants of income velocity of money. We also conclude that in short-run, there is limited evidence that industrial production and short-term interest rates significantly influence the income velocity of money.

It is crucial to consider robustness checks of our findings. To do so, we have simply included two structural break dummy variables in our short-run models. These structural break dates are obtained using the NP (2010) two-structural break unit root test as mentioned earlier. The break dates considered are December 2012 and June 2014 and we denote them as dummies, D1 and D2, repectively. These additional results are reported in Table 6. Overall, our findings are robust to the inclusion of breaks - that is, our main conclusions do not change when structural breaks are modelled. In addition, we also note that structural breaks are reasonably important to be included in our estimation models. For instance, we find that the second break dummy (associated with the second structural break (i.e. June 2014)) is statistically significant in $50 \%$ of the cases. 


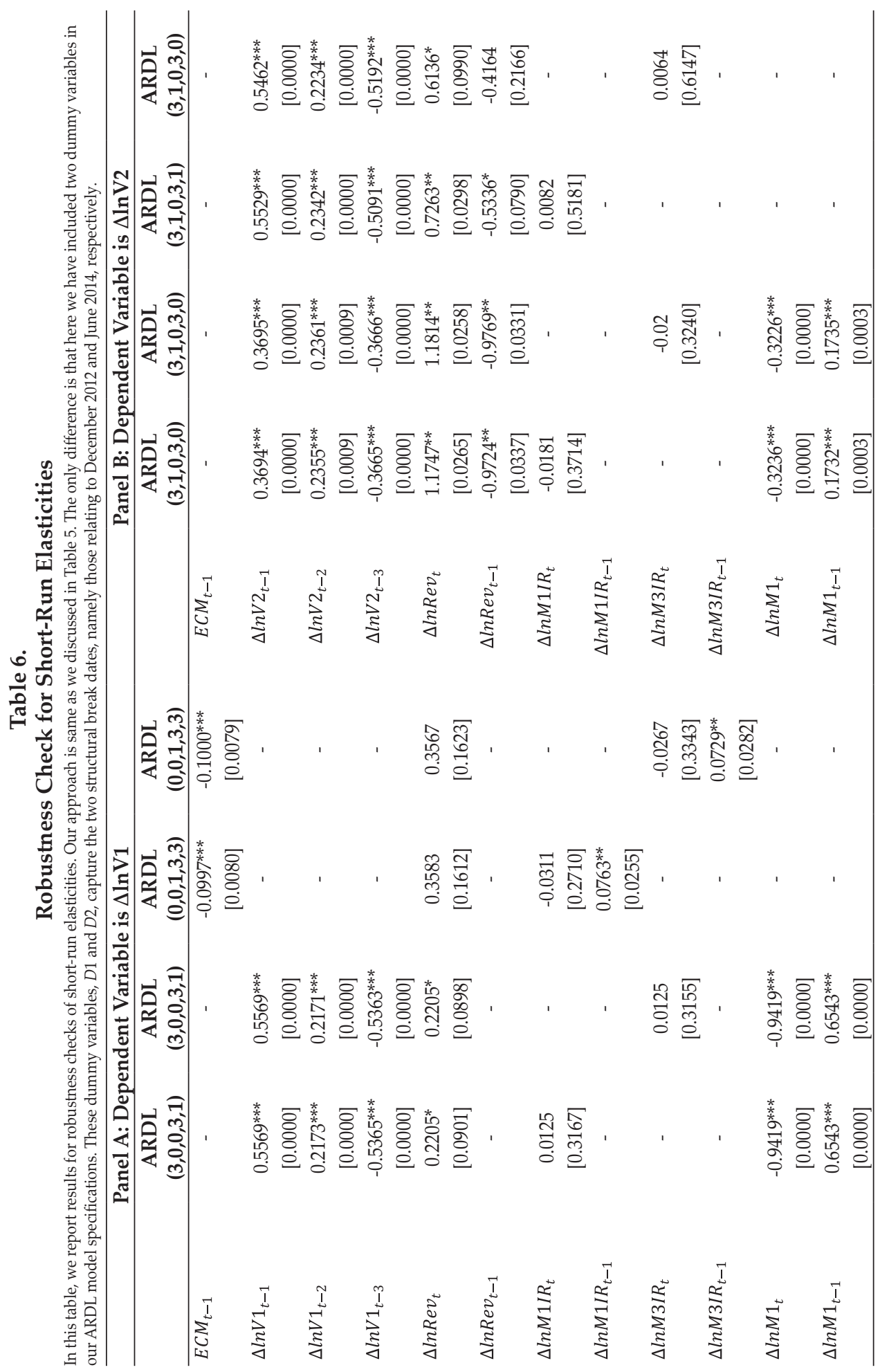




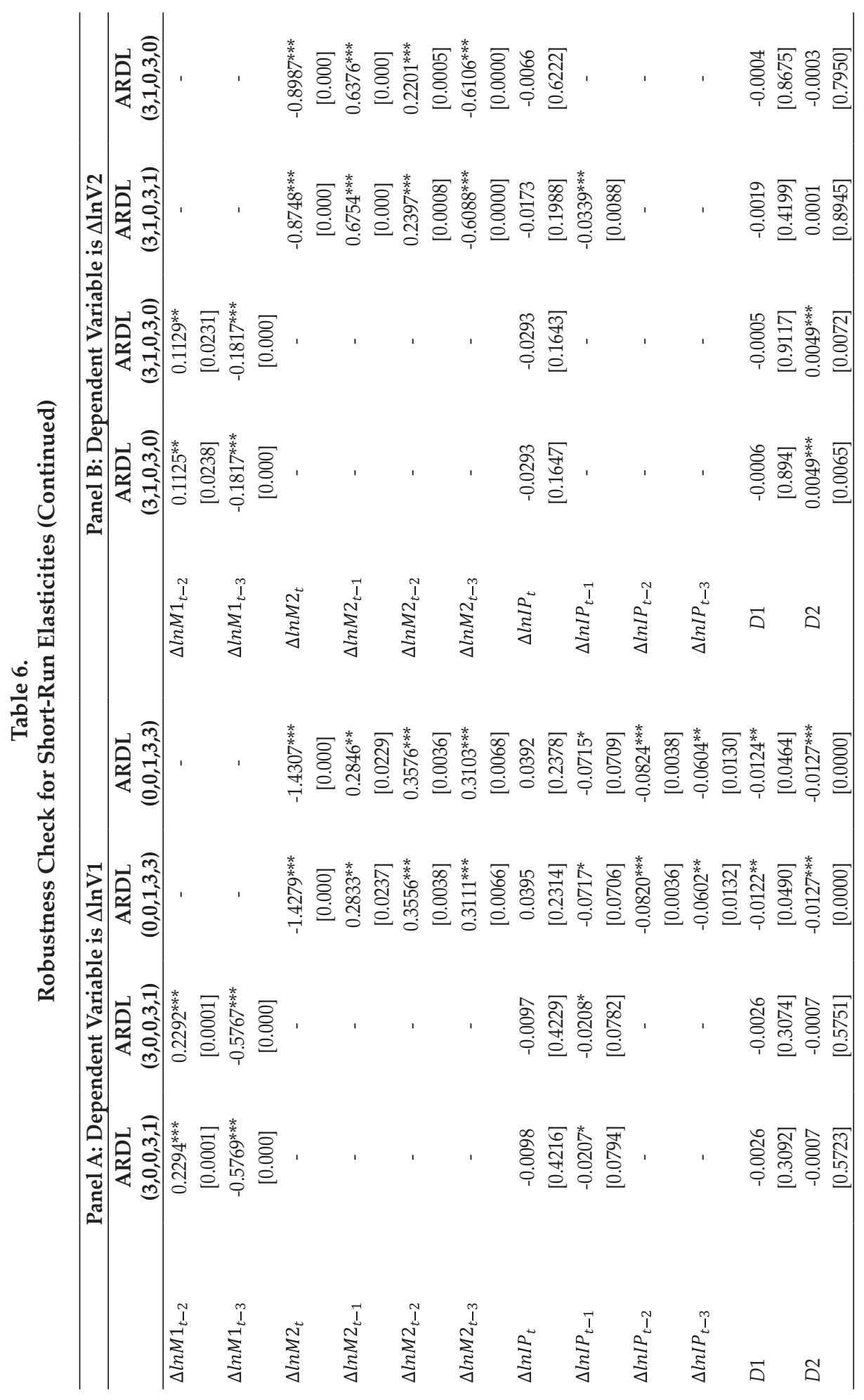




\section{CONCLUSION}

This paper examines the determinants of income velocity of money for Indonesia. We use monthly time-series data for income velocity of money, money demand (M1 and M2), short-term interest rates (1-month and 3-month), industrial production, and local government tax revenue over the period December 2000 to December 2017. Our approach in examining the determinants of income velocity of money are as follows. First, we examine the order of integration of all variables using commonly known ADF unit root test as well as the NP (2010) unit root test which allows for two endogenous structural breaks in the data series. Second, we examine the null hypothesis of "no cointegration" using the ARDL bounds test for cointegration. In the final step, we estimate the long-run and short-run elasticities.

Our findings are as follows. (1) We find some evidence of cointegration between income velocity of money and the other four variables (industrial production, tax revenue, money demand (only M2), and short-term interest rates). (2) In the longrun, we show that tax revenue, short-term interest rates, and industrial production significantly determine Indonesia's income velocity of money. Our results are robust to multiple estimators, suggesting that econometric methods do not dictate our conclusions. (3) We document that money demand significantly determines income velocity of money in the short-run. We do find mixed evidence in support of industrial production, tax revenue, and short-term interest rates significantly determining the income velocity of money in the short-run. Our results remain insensitive to the inclusion of structural breaks.

The policy implications are obvious from our research. The income velocity of money demonstrates the rate at which money in circulation is used for transactions in the economy. The income velocity of money is used by investors to judge the investment potential of an economy. We know from our work that tax revenue, short-term interest rate, and industrial production impact income velocity of money. Monetary policy, such as changes in the interest rate/inflation rate, will impact tax revenue and industrial production and will have a direct effect on velocity through the short-term interest rate. Therefore, monetary authorities, if the goal is to stabilize income velocity of money, need to take account of the fact that monetary policy will impact velocity.

\section{REFERENCES}

Akinlo, A. E. (2012). Financial Development and the Velocity of Money in Nigeria: An Empirical Analysis. The Review of Finance and Banking, 4, 97-118.

Altayee H.H.A., and Adam, M.H.M. (2013). Financial Development and the Velocity of Money Under Interest-Free Financing System: An Empirical Analysis. American Based Research Journal, 2, 53-70.

Bordo, M.D., and Jonung, L. (1981). The long-run behaviour of the income of money in five advanced countries. 1870-1975: An institutional approach. Economic Inquiry, 19, 96-116.

Bordo, M.D., and Jonung, L. (1990). The long-run behaviour of velocity: an institutional approach revisited. Journal of Policy Modelling, 12, 165-197.

Bordo, M.D., Jonung, L., and Siklos, P. (1993) The Common Development of Institutional Change as Measured by Income Velocity. A Century of Evidence from Industrialised Countries. NBER Working Paper No 4379. 
Chandavarkar, A. G. (1977). Monetization of Developing Economies. IMF Staff Papers, 24, 665-721.

Dickey, D.A., and Fuller, W.A. (1979). Distribution of the Estimators for Autoregressive Time Series With a Unit Root. Journal of the American Statistical Association, 74, 427-431.

Friedman, M., and Schwartz, A.J. (1963). A Monetary History of the United States, 1867-1960. Princeton University Press.

Holmes, J. M., and Smyth, D.J. (1972). The Specification of the Demand for Money and the Tax Multiplier. Journal of Political Economy, 80, 179-85.

Ireland, P.N. (1991). Financial Evolution and the Long-Run Behaviour of Velocity: New Evidence from US Regional Data. FRB Richmond Economic Review, 77, 16-26.

Jung, A. (2017). Forecasting Broad Money Velocity. North American Journal of Economics and Finance, 42, 421-432.

McGibany, J., M., and Nourzac, F. (1985). Income Taxes and the Income Velocity of Money: An Empirical Analysis. Journal of Macroeconomics, 7, 523-535.

Mele, A., and Stefanski, R. (2018). Velocity in the Long Run: Money and Structural Transformation. Review of Economic Dynamic, In Press.

Narayan, P.K. (2005). The Saving and Investment Nexus for China: Evidence from Cointegration Tests. Applied Economics, 37, 1979-1990.

Narayan, P.K., and Popp, S. (2010). A New Unit Root Test with Two Structural Breaks in Level and Slope at Unknown Time. Journal of Applied Statistics, 37, 1425-1438.

Narayan, P.K. and Popp, S. (2013). Size and Power Properties of Structural Break Unit Root Tests. Applied Economics, 45, 721-728

Narayan, P. K., Narayan S., Rahman, R. E., and Setiawan, I. (2018). Bitcoin Price Growth and Indonesia's Monetary System. Emerging Markets Review, In Press.

Newey, W. K., and West, K. D. (1987). A Simple, Positive Semi-definite, Heteroskedasticity and Autocorrelation Consistent Covariance Matrix. Econometrica, 55, 703-708.

Okafor, P.N., Shitile, T.S., Osude, D., Ihediwa, C.C., Owolabi, O. H., Shom, V.C., and Agbadaola, E.T. (2013). Determinants of Income Velocity of Money in Nigeria. Central Bank of Nigeria, Economic and Financial Review, 51, 29-59.

Pierce, J. L., and Thomson, T. D. (1972). Some Issues in Controlling the Stock of Money. Controlling Monetary Aggregates II: The Implementation, Federal Reserve Bank of Boston Conference Series, 9, 115-36.

Poole, W. (1970). Optimal Choice of Monetary Policy Instruments in a Simple Stochastic Macroeconomic Model. Quarterly Journal of Economics, 84, 197-216.

Short, B.K. (2007). The Velocity of Money and Per Capita Income in Developing Economies: Malaysia and Singapore. The Journal of Development Studies, 9, 291300 .

Sharma, S.S., Tobing, L., and Azwar, P. (2018). Understanding Indonesia's Macroeconomic Data: What Do We Know and What are The Implications? Bulletin of Monetary Economics and Banking, 21, 229-264.

Tatom, J.A., (1983). Was the 1982 Velocity Decline Unusual? Federal Reserve Bank of St. Louis Review, 5-15.

Thornton, D.L., (1983). Why Does Velocity Matter? Federal Reserve Bank of St. Louis Review, 5-13. 


\section{APPENDIX}

Table A.

Data Definition and Source

This table describes each variable, its calculation (where applicable), frequency, and its source.

\begin{tabular}{|c|c|c|c|c|}
\hline Variable & Definition & $\begin{array}{c}\text { Authors } \\
\text { Calculation }\end{array}$ & Frequency & Source \\
\hline $\ln V 1$ and $\ln V 2$ & $\begin{array}{l}\text { Income velocity of } \\
\text { M1 and M2. Here, } \\
\text { M1 represents } \\
\text { nominal money } \\
\text { supply which } \\
\text { is money in } \\
\text { circulation and } \\
\text { demand deposits } \\
\text { and M2 is simply } \\
\text { M1 plus time } \\
\text { deposit. }\end{array}$ & $\begin{array}{l}\ln V 1=\log (P Y / M 1) \\
\ln V 2=\log (P Y / M 2)\end{array}$ & Monthly & Bloomberg \\
\hline $\ln M 1$ and $\ln M 2$ & $\begin{array}{c}\text { Demand for Money } \\
\text { (M1 and M2) }\end{array}$ & $\begin{array}{l}\ln M 1=\log (M 1) \\
\ln M 2=\log (M 2)\end{array}$ & Monthly & Bloomberg \\
\hline $\ln I P$ & $\begin{array}{c}\text { Industrial } \\
\text { production }(I P)\end{array}$ & $\ln I P=\log (I P)$ & Monthly & Bloomberg \\
\hline $\begin{array}{l}\ln M 1 I R \text { and } \\
\ln M 3 I R\end{array}$ & $\begin{array}{l}\text { One-month (M1IR) } \\
\text { and three-month } \\
\text { (M3IR) interbank } \\
\text { rates. }\end{array}$ & $\begin{array}{l}\ln M 1 I R=\log (M 1 I R) \\
\ln M 3 I R=\log (M 3 I R)\end{array}$ & Monthly & Bloomberg \\
\hline $\ln \operatorname{Rev}$ & $\begin{array}{c}\text { Revenue from } \\
\text { Indonesia's } \\
\text { government tax } \\
\text { (Rev). }\end{array}$ & $\ln \operatorname{Rev}=\log (\operatorname{Rev})$ & Annual & Bloomberg \\
\hline
\end{tabular}

